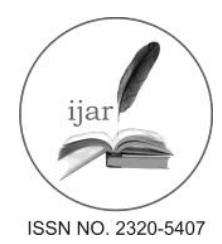

Journal homepage:http://www.journalijar.com

Journal DOI:10.21474/IJAR01

RESEARCH ARTICLE
INTERNATIONAL JOURNAL

OF ADVANCED RESEARCH

\title{
Studying the Views of the Students of Payam Nour University (PNU) of Urmia İran about Marriage and Engagement.
}

\section{Ali Davtalab ${ }^{1}$ and TugcaPoyrazTacoglu ${ }^{2}$.}

1. Department of Sociology, Humanities College, PayamNour University, Bahonar St., 8 Sheriver Urmia, Iran.

2. Department of Sociology,Institute of Social Sciences, Hacettepe University, PO BOX 06800, Ankara, Turkey.

\section{Manuscript Info}

Manuscript History:

Received: 12 April 2016

Final Accepted: 19 May 2016

Published Online: June 2016

Key words:

Marriage, youth, premarital counseling, the nomination period

*Corresponding Author

Ali Davtalab.

\section{Abstract}

Introduction and purpose: Present study has examined university students' views on marriage and engagement period.

Materials and methods: This study was conducted in the first semester of the academic year 2014-2015 in Urmia PNU, humanities college among senior students who were seventy. This study was conducted aimed to evaluate the demographic characteristics of students and their parents by researcher through survey method and using a researcher-developed questionnaire.

Research findings: Study population of the study consisted of $58.6 \%$ female students and $41.4 \%$ male students, of whom 80 percent were 20 to 22 years old and 20 percent were 23 years and more. The engagement period of $88.6 \%$ of students was less than a year, $7.1 \%$ was between 1 to 2 years, and $4.3 \%$ have been engaged for three years and more. Generally, students and their parents' income is average, more than $94.2 \%$ see marriage as accountability, and $98.5 \%$ of them have understood mutual understanding in life. They consider the age between 25 and 29 as suitable for marriage and more than half them $(57.1 \%)$ are intended to get married with their current fiancée. About traits of the person to whom they want to get married, being kind (94.2\%) and being educated (97.1\%) were considered and 82.9 know their decision asprior to their family and $84.3 \%$ of the students are not optimistic about online friendship and marriage.

Conclusions: The results of this study show that young people generally have a sensitive approach toward marriage, but they are hopeful. Despite the problems of engagement period and not being comfortable, couples have considered elongation of this period and referring to specialized counseling before marriage as essential.

Copy Right, IJAR, 2016,. All rights reserved.

\section{Introduction:-}

Marriage and marital issues have been and are among the important issues of human life throughout the history. Therefore, this issue, in addition to religions, has been paid attention to in different scientific fields such as sociology, law, economics, psychology, philosophy and so on. (Ozguven, 2000:21 )

Forming a family as a small society unit is of great importance in human life. Family functioning and its impact on people make the importance of its formation double (Gunay, 1995: 5 ). Marriage is a complex task that is between two people who did not know each other previously and is for forming a set to solve their problems in social relationships (Ozguven, 2000:21 ). Both in the world and in Iran, in the recent period the rapid changes, often because of new technological and economic conditions, have affected our cultural and social fields ( Cigdem, Dikecligil,1990: 206). 
With formation of a family and unity of man and woman, along with children and relatives, new relationships are created that by making the right decision and guiding life in a favorable way, despite many difficulties, hope and success are provided for people in forming a family (Altun,1994:15 ).

If a family is based on the correct basis, the future life of the person is affected by it, meaning that the person has prepared himself before getting married on such issues as knowing oneself, correct relationship, feeling intimacy, and having a sense of responsibility ( Stephen, , Duncan, , Holman,2007:270). Forming a family ensures community health and development so today, in Western societies various methods have been applied for the development and institutionalization of marriage ( Stephen, , Duncan, , Holman,2007:270)and ( Scott, MS., Paul, RA., Christine AJ., Howard, JM,2006:117).

Sustainability and community health in social and family life are very important and young people's taking responsibility for this is considered more important. Since the formation of the independent character of a young person is in the young hood along with other members of the family, young people are expected to be determined in choosing a spouse and a family (8(Halford, Simons ,2005:147 ) - and ( Martin,Specter, Martin, 2003:359).

Youth is a very sensitive period. Doubts, dreams of the future, feelings, and misinformation on the part of friends in the decision to form a family leave a negative impact ( Suzer, Y1ldiz,2005:24) and( Stahmann,2000:104 ). Therefore, forming a family for students, especially non-native students who live away from parents is of utmost importance. The engagement period is a period of mediocrity that person is prepared to enter into marriage. During this period, the fiancés' connection with each other becomes more, and in this more relationship, people's understanding from each becomes deeper( Sadeghi, 1985: 151).

\section{Theoretical Framework:-}

Social scientists are very interested to know why two people choose each other for marriage and as a spouse. In this regard, some views are expressed that we explain some of them.

\section{A. Hector' rational choice theory}

Fundamental distinction between this theory and other theories put forward about marriage is that most of the theories of marriage view it more as a moral act, but this theory sees it more from a utilitarian view.

Thinkers like Littel that explain collective action based on rational choice theory believe that people have tendency to behaviors in which their profit is higher. This theory believes that these conscious and purposeful people seek to maximize their profits in all circumstances (Littel, 1994:69).

Regarding marriage by using the theory of rational choice, it can be confirmed that people will try to marry when there is an interest in it, that is they can maintain their social status or improve it through marriage.

\section{B. Complementary need theory}

This theory was developed by Robert Winch et al in 1951. This theory states that humans have a series of needs that can be met through social relations, needs such as: the need for emotional support, care, and sexual gratification. The main assumption of the theory is that among a selection of qualified individuals, prople whose needs pattern provides mutual satisfaction choose each other as partners. People select spouses who meet the most needs for them. Maximum meeting of needs happens when the needs of man and woman are complementary rather than similar to each other (William Goode 1982: 14).

\section{The theory of balance}

The basic theory about mate selection is thetheory of balance by Heider (1985). In general, it notes that, if a person chooses a person as spouse who has the same thoughts and feelings about the ideas, people, and events around have him, then less stress is created for the person. Humans usually feel comfortable with people who think and feel like them, they communicate better with them and there is less argument between them. They mostly talk and enjoy being together.

\section{Review of Related Literature:-}

In her research as "Studying the point of view of men and women towards marriage and accepting the role of father and mother," Behijeh Akshi (1998) in Corum Turkey, by survey method randomly selected a sample of 100 men and 
women, among whom $75 \%$ were households of urban nucleus families and $25 \%$ were rural households. In the results of the study, $81 \%$ of participants stated marriage as choosing a wife and a friend and often stated the time of having children after a year of marriage. Eighty-eight point five percent of the participants said parenthood for raising a child and expressed that having a healthy family and community depends on the selection of a healthy spouse( Ekshi,2005:75).

Jean Paul Sardin has studied marital status in 21 European countries using generation and cluster analyses to show the differences between Eastern and Western Europe marriage patterns. His research findings indicated that in the past two decades, in Eastern Europe marriage has been early and more common. However, in Western Europe, it is opposite and even high proportion of people have never married. In addition, Sardin found that the average age at first marriage for men and women of Eastern Europe is, respectively, 25.1 and 22.1, while similar figures in Western Europe have been 27.2 and 24.8 ( Sadeghi, 1985: 157).

Lishter et al (1992), in their studies have concluded that tendencies towards the importance of marriage and family and women's roles in marriage are effective in the age of marriage. Young women who less believe in traditional values are more likely to postpone marriage for the sake of higher education or entering the workforce (Lishter, 1992: 180).

Mir Mohammad Sadeghi (1985) in his work titled "Marriage, premarital education" has discussed the main issues of choosing a spouse, correct and incorrect reasons of marriage, criteria and standards of a successful marriage, predictors of successful marriage, and understanding. Then he has presented a definition of engagement and its importance and has suggested the length of engagement from 6 months to 3 years (Sadeghi, 1985:172).

\section{Research Methodology:- \\ Purpose:-}

This study was conducted to examine the views of young students of Payam Noor University of Urmia towards marriage.

\section{Materials and methods:- \\ Methods:-}

This study is descriptive-explanatory

\section{The population and sample of the study:-}

This study was conducted during the academic year 2014-15 first semester in PNU of Urmia among final year students of social science (population=88). From among those engaged, 70 people were randomly selected as the sample based on Morgan Table.

\section{Data collection:-}

The researcher has proceeded to develop questionnaire based on characteristics of students, marriage and divorce, the introduction period of their engagement and by referring to literature ( Scott, MS., Paul, RA., Christine AJ., Howard, JM,2006:117) and(Halford, Simons ,2005:147 ). Participants' having a fiancé is considered as a criterion in the study, so before distributing the questionnaire, a preliminary interview was held with the participants about the objectives and content of the questionnaire, and they read consent form and their approval of it was requested. The questionnaire was distributed among the students in the period from fifth to 25 December 2014 by researcher and was completed and returned in about 15 minutes. In analysis of data, chi test was used for content and the validity of test. The significance level of data was 0.05 . 


\section{Data Analysis and Findings:-}

Table 1: Distribution of students according to some biographical features

\begin{tabular}{|c|c|c|}
\hline Biographical features & Frequency $\mathrm{N}$ & Percent \\
\hline \multicolumn{3}{|l|}{ Gender } \\
\hline Woman & 41 & 58.6 \\
\hline Man & 29 & 41.4 \\
\hline \multicolumn{3}{|l|}{ Age } \\
\hline $20-22$ & 56 & 80.0 \\
\hline 23 and higher & 14 & 20.0 \\
\hline \multicolumn{3}{|c|}{ Education level of spouses of engaged students } \\
\hline Diploma & 13 & 18.57 \\
\hline MA/MS and higher & 27 & 24.36 \\
\hline University student & 40 & 57.13 \\
\hline \multicolumn{3}{|c|}{ Status of the length of engagement period } \\
\hline Less than a year & 62 & 88.6 \\
\hline $1-2$ years & 5 & 7.1 \\
\hline 3 years and more & 3 & 4.3 \\
\hline \multicolumn{3}{|c|}{ Where have you mostly lived until this year? } \\
\hline Provincial capital & 58 & 82.5 \\
\hline City & 12 & 17.5 \\
\hline \multicolumn{3}{|l|}{ Students living situation } \\
\hline Good & 40 & 57.1 \\
\hline Average & 25 & 35.7 \\
\hline Weak & 5 & 7.2 \\
\hline Total & 70 & 100.0 \\
\hline
\end{tabular}

In Table 1, as can be seen of men and 58.6\% are men $41.4 \%$ are women, 80 percent are between the ages of 20-22 years and 20 percent 23 years and more (Table1), 57\% of students' fiancés are university students, 24.36 MA/MS and higher and $18.57 \%$ high school graduates.

The engagement period for students: $88.6 \%$ of students less than a year, 7.1 percent between one and two years and only $4.3 \%$ three years and more three years. İn terms of location, $82.5 \%$ have live for many years in the provincial capital and $17.5 \%$ in the city. Finally, in terms of living conditions, $57.1 \%$ are good, $35.7 \%$ are average and $7.2 \%$ are weak(1).

(1). Min: 20, max. 27 
Table 2: Students' attitudes regarding marriage

\begin{tabular}{|c|c|c|}
\hline Criteria in relation to marriage & Frequency & Percent \\
\hline \multicolumn{3}{|c|}{ In your opinion, what does the concept of marriage state? } \\
\hline Accountability & 66 & 94.2 \\
\hline Understanding, coexistence & 69 & 98.5 \\
\hline Hope & 33 & 47.1 \\
\hline Regular life & 23 & 32.8 \\
\hline Uniformity & 18 & 25.7 \\
\hline \multicolumn{3}{|c|}{ In your opinion, what is the right age for marriage? } \\
\hline $20-24$ & 24 & 34.2 \\
\hline $25-29$ & 46 & 65.8 \\
\hline \multicolumn{3}{|c|}{ In your opinion, what is the right age of men for marriage? } \\
\hline $20-24$ & 13 & 18.6 \\
\hline $25-29$ & 41 & 58.6 \\
\hline $30-34$ & 16 & 22.8 \\
\hline \multicolumn{3}{|c|}{ Currently, are you willing to marry your partner? } \\
\hline Yes, I do & 40 & 57.1 \\
\hline No, I do not & 9 & 12.9 \\
\hline I have not decided & 21 & 30.0 \\
\hline \multicolumn{3}{|c|}{ How do you expect your future spouse to be? } \\
\hline Elegant / stylish & 44 & 62.8 \\
\hline Be good-natured & 66 & 94.2 \\
\hline Be educated & 68 & 97.1 \\
\hline Have the same culture & 33 & 47.1 \\
\hline Have the world view close to mine & 57 & 81.4 \\
\hline \multicolumn{3}{|l|}{ How do you decide in mate selection,? } \\
\hline First, I decide then inform my family & 58 & 15.7 \\
\hline First, I inform my family then I decide & 12 & 17.1 \\
\hline \multicolumn{3}{|l|}{ What do you think about online marriage? } \\
\hline$\dot{\mathrm{I}}$ am optimistic & 11 & 15.7 \\
\hline İ do not approve of it & 59 & 84.3 \\
\hline
\end{tabular}

In Table 2 as can be seen, students have mostly seen marriage as to take responsibility (94.2\%) and understanding and cohabitation (98.2\%). Students have considered suitable marriage ages as $25-29$, more than half (57.1\%) have decided to get married to their partner. Regarding traits, (94.2\%) want the spouse to be good-tempered, (97.1\%) educated, and $82 \%$ consider their own decision in selecting a spouse prior to family. Among respondents married $84.3 \%$ are not optimistic about online and virtual conversations of young people about the marriage. 
Table 3: The existing feature in connectionwith sexual relations

\begin{tabular}{|c|c|c|}
\hline İtems related to sexual relations & Frequency & Percent \\
\hline \multicolumn{3}{|l|}{ Which marriage of yours is this? } \\
\hline The first one & 52 & 74.2 \\
\hline The second or more & 18 & 25.8 \\
\hline \multicolumn{3}{|c|}{ Do you feel comfortable in talking about sexual matters with your partner? } \\
\hline Yes, I do & 21 & 30.0 \\
\hline No, I do not feel so comfortable & 49 & 70.0 \\
\hline \multicolumn{3}{|c|}{ Have you received professional advice on sexual matters? } \\
\hline Yes, I have & 54 & 77.1 \\
\hline No, I have not & 16 & 22.9 \\
\hline \multicolumn{3}{|l|}{ Identify the topics you have received advice at. } \\
\hline In the case of sexually transmitted diseases & 63 & 90.1 \\
\hline About ways to prevent pregnancy & 52 & 74.3 \\
\hline Sexual dysfunction & 53 & 75.4 \\
\hline Spousal relationship on conjugal issues & 40 & 57.1 \\
\hline \multicolumn{3}{|l|}{ Where have you received advice? } \\
\hline Expert Advice Center & 40 & 74.0 \\
\hline Hospital / personal physician & 14 & 26.0 \\
\hline
\end{tabular}

İn Table 3, as you can see 87.1 percent have experienced their first marriage, $70 \%$ are not comfortable speak about sexual issues with their partner not and $77.1 \%$ have received counseling before marriage ceremony. $74 \%$ have received sex advice from Expert Advice Center, 90.1\% have received advice about transmission of sexually transmitted diseases, $74.3 \%$ about contraceptives, and $75.4 \%$ about sexual dysfunction.

Table 4: Interview in connection with divorce

\begin{tabular}{|l|l|l|}
\hline Criteria related to divorce & Frequency & Percent \\
\hline What percentage do you think is the likelihood of divorce in our country? & 18.5 \\
\hline$<30$ & 13 & 45.7 \\
\hline $40-60$ & 32 & 35.8 \\
\hline$>70$ & 25 & 77.1 \\
\hline In which year of marriage, do you think that divorce happens more? & 21.4 \\
\hline $0-5$ years & 54 & 1.4 \\
\hline $6-10$ years & 15 & \\
\hline $11-15$ years & 1 & 55.7 \\
\hline In which period of life does divorce happen more? & \multicolumn{2}{|l|}{} \\
\hline Before the babies born & 39 & 41.4 \\
\hline After the babies born & 29 & 2.9 \\
\hline After the separation of children from home & 2 & 87.1 \\
\hline "Misunderstanding" leads to the couple's divorce, do you approve this? & 12.9 \\
\hline Yes, I do. & 61 & \\
\hline No, I do not. & 9 & 65.7 \\
\hline In your opinion, what consequences does divorce create between couples? & 81.4 \\
\hline Children live apart from their father or mother & 46 & 50.0 \\
\hline Violence in the family becomes less & 57 & 70.0 \\
\hline Economic power of the family grows & 35 & 45.7 \\
\hline The new order comes in life & 49 & 64.2 \\
\hline Feeling lonely & 32 & \\
\hline Not respecting oneself & 47 & \\
\hline
\end{tabular}


In Table 4: 45.7 percent of engaged couples have stated the likelihood of divorce between $60-40$ percent, in the first 5 years of life $77.1 \%$, and $55.7 \%$ before having a child, and $87.11 \%$ of the participants have expressed reason for divorce of couples as misunderstanding.

Of the respondents to the question "What is the impact of divorce in the family?" $81.4 \%$ have seen divorce as the factor to decrease differences and argument within the family and 70\% Systems have announced it to cause a new family lifestyle.

Table 5: The quality of participation of engaged students in connection with the marriage

\begin{tabular}{|c|c|c|c|c|c|c|c|c|c|c|}
\hline \multirow{3}{*}{$\begin{array}{lll}\text { Items } & \text { related } & \text { to } \\
\text { marriage } & & \end{array}$} & \multicolumn{10}{|c|}{ Commenting on the status of items } \\
\hline & \multicolumn{2}{|c|}{$\begin{array}{l}\text { Totally } \\
\text { disagree }\end{array}$} & \multicolumn{2}{|c|}{ Disagree } & \multicolumn{2}{|c|}{ No idea } & \multicolumn{2}{|c|}{ Agree } & \multicolumn{2}{|c|}{ Totally agree } \\
\hline & $\mathrm{n}$ & $\%$ & $\mathrm{n}$ & $\%$ & $\mathrm{n}$ & $\%$ & $\mathrm{n}$ & $\%$ & $\mathrm{n}$ & $\%$ \\
\hline $\begin{array}{l}\text { Get counseling before } \\
\text { marriage }\end{array}$ & 5 & 7.1 & 14 & 20.0 & 15 & 21.4 & 25 & 35.7 & 20 & 28.6 \\
\hline Hope is accessible & 8 & 11.4 & 11 & 15.7 & 26 & 37.1 & 18 & 25.7 & 13 & 18.6 \\
\hline $\begin{array}{l}\text { Now, I have no } \\
\text { communication } \\
\text { problems }\end{array}$ & 29 & 41.4 & 18 & 25.7 & 8 & 11.4 & 9 & 12.9 & 6 & 8.6 \\
\hline $\begin{array}{l}\text { In connection with my } \\
\text { fiancé, we solve our } \\
\text { problems }\end{array}$ & 3 & 4.3 & 1 & 1.4 & 14 & 20.0 & 19 & 27.1 & 33 & 47.1 \\
\hline $\begin{array}{l}\text { Due to the time of } \\
\text { engagement period, it is } \\
\text { possible to terminate }\end{array}$ & 25 & 35.7 & 23 & 32.9 & 14 & 20.0 & 4 & 5.7 & 4 & 5.7 \\
\hline $\begin{array}{l}\text { I think of sexual } \\
\text { problems after marriage }\end{array}$ & 3 & 4.3 & 7 & 10.0 & 27 & 38.6 & 17 & 24.3 & 16 & 22.9 \\
\hline $\begin{array}{l}\text { If I get divorce from my } \\
\text { fiancé e, I remarry }\end{array}$ & 22 & 31.4 & 16 & 22.9 & 17 & 24.3 & 8 & 11.4 & 7 & 10.0 \\
\hline
\end{tabular}

In Table 5: Most students wanted pre-marital counseling, (64.4\%); hope in life cannot easily be achieved, (44.3\%); currently do not have a problem with their partner, (67.1\%); compromise and agreement in the problems, those who think thin of the likelihood to experience problems after marriage, $(74.2 \%)$; and no optimistic to remarry after separation $(54.3 \%)$.

$$
\left(\mathrm{X}^{2}=0.620 \mathrm{P}=0.734 \mathrm{P}>0.05\right)
$$

Marriage relations were examined by age of students, the views of female students, who were engaged, towards completion and married life is far more than that in men. At the same time, female students do not consider divorce at engagement as acceptable and have opposed remarriage, but statistically no significant difference was observed between them.

$$
(\mathrm{X} 2=0.620 \mathrm{P}=0.734 \mathrm{P}>0.05)
$$

Female student see marriage as understanding, hope, responsibility, and at the same time, male students see it as to have a regular life, responsibility and understanding.

$$
\left(\mathrm{X}^{2}=1.806 \mathrm{P}=0.42 \quad \mathrm{P}>0.05\right)
$$

Students of both sexes have stated the probability of divorce between $60-40 \%$ and within the first 5 years of marriage.

$$
\begin{aligned}
& \left(\mathrm{X}^{2}=2.582, \mathrm{P}=0.275, \mathrm{P}>0.05\right) \\
& \left(\mathrm{X}^{2}=3.481, \mathrm{P}=0.303, \mathrm{P}>0.05\right)
\end{aligned}
$$

There was no significant difference between them and male students believe that the possibility of divorce before the birth of children is more and female students believe that, it occurs more after the birth of a child.

$$
\left(\mathrm{X}^{2}=4.266, \mathrm{P}=0.118, \mathrm{P}>0.05\right)
$$

Both have the same opinion about the results of divorce.In the results of the items related to marriage, female students want premarital counseling more than the male ones.

$$
\left(\mathrm{X}^{2}=2.334, \mathrm{P}=0.345, \mathrm{P}>0.05\right)
$$

In relation to the question about "Being hopeful in the marriage is easy" those who have a negative response.

$$
\left(\mathrm{X}^{2}=8.713, \mathrm{P}=0.069, \mathrm{P}>0.05\right)
$$


Those who are able to continue living together despite problems.

$$
\left(\mathrm{X}^{2}=2.110, \mathrm{P}=0.456, \quad \mathrm{P}>0.05\right)
$$

The percent of students who want to marry a person their par scientific level in this study are $40 \%$.

$$
\left(\mathrm{X}^{2}=12.30, \mathrm{P}=0.046, \mathrm{P}<0.05\right)
$$

\section{Discussion:-}

Not being ready for marriage and hasty decisions, despite the short period of engagement cause a lot of problems to young people (Silliman, Walter,2004:513) and(Halford, Simons ,2005:147 ). However acquiring the necessary skills and experience is necessary for couples ( Martin, Specter, Martin, 2003:359). Therefore, young people assume the greatest risk in marriage. In this study, students who were interviewed are generally serious in marriage and want engagement to be for family formation with certainty (Table 2.1). In a similar study, this issue was studied by a Turkish researcher Ekshi and the participants stated understanding and trust as the main purpose of marriage $(\mathrm{P}<0.05)$.

In our society, because of cultural and socioeconomic changes arisen, different views have been proposed for marriage. Especially women's involvement in social issues, the issue of aging in the marriage age, and the views of the youth to choose a spouse have changed. Despite these issues, importance of marriage has a great status in Iran. Within this study, students see Internet marriage as inappropriate $(84.3 \%)$ and on the subject of marriage to future spouse, they put their priorities with their own decision (82.9\%). Most students have preferred marrying a beautiful, stylish, and educated spouse (Table 2). In general, young people are more focused on their decision. Marrying of men and women to start living happens with a bilateral agreement and this is true about decisions made about the education of children. However, it is said that the young people live in a dual and fantasy world about marriage (Martin, Specter, Martin, 2003:359)and(Stahmann,2000:104 ). According to research by Turkish researchers Arsalan and Demirkahn in 12 Turkish universities, most students see appropriate marriageable age as 29-25.

In a similar study, $81.2 \%$ students put their own decision about marriage in priority and placed their parents in the next category ( $87.1 \%$ girls, $74.8 \%$ boys). $56.5 \%$ of students disagreed with online marriage that is similar to the results of this study. In this study, they have announced that among three students one was relax talking about issues related to sex $(33.33 \%)$. On getting advice, it was specified getting it from professional consultants $(77.1 \%)$, from the center of expert advice (74\%), about sexually transmitted diseases $90.1 \%$, pregnancy issues $74.3 \%$, and about sexual dysfunction $75.4 \%$ (Table 3 ).

The results of this study are consistent with the results of the work by Ozlemcan et al (Arslan, Engin, Can, 2000:94) in Turkey $(\mathrm{n}=1000)$. On a larger scale, women show avoiding pregnancy as 69.6, preventing sexual diseases $60.7 \%$, and the period of being pregnant as $51.8 \%$. In this study, students of both sexes have stated the probability of divorce between $60-40 \%$ and within the first 5 years of marriage (Table 4 ).

According to research conducted within the country, increased rate of divorce than the previous years is seen: divorce from 94 thousand divorces in 2006 has reached 110 thousand in the year 2008, 137 thousand in 2010 has reached 150 thousand in 2012, and 160 thousand in year 2014 (Statistical Center of Iran ,2009).

Of course, these figures are lower compared to neighboring Turkey and other Western countries. Generally, in Iran, 44.8 percent of divorces occur in the first 5 years of marriage ( Turkish Prime,2006:14). In countries like America, percent of divorce is between 40-60 percent, where 18\% of couples have divorced in the first year of life. Couples together-life length in America has been recorded an average of 6 years so; even not married they think of divorce (Sullivan,2004:175).

In this study, lack of understanding of the couple's about divorce was granted as normal, decrease of discussion among couples indoors and forced child responsibility with the parent, decreased or increased financial strength, loneliness, feelings of inferiority and changes in lifestyle have been declared as the results of divorce (table 4). $(\mathrm{P}<0.05)$

In a study conducted in 2005 (Ekshi, 2005: 45), divorce results are discussed and the findings are as follows: physical health $54.8 \%$, mental health $57.4 \%$, monetary growth $27.5 \%$, self-confidence $42.6 \%$, and quality of life 38.7 are negatively affected after divorce. 
In relation to the subject of research, other studies have been done showing that premarital counseling programs have significant effects (Sullivan,2004:175) and (Vural, Temel,2007:34) .

In divorce, re-marriage of girls is less than male students. $(\mathrm{P}>0.05)$

This is while, in the research by Ekshi, the tendency to remarry among women is more than in men. $(\mathrm{P}<0.05)$

Sex plays an important role in the strength of family and evolution of male and female. Getting married is not just having sexual relations, but in the event of a sexual problem couples divorce under the Civil Code (Purnine, Carey,1997:1017). Divorce is said to be closely associated with social functioning, psychological, and physical health of the couple's (Dunn, Croft, Hackett, 2000:141 ). However, most students believe in a direct relationship between the engagement period and establishment of family, this means as the engagement period is prolonged recognition of couples and their understanding will be more.

In this study, only $28.2 \%$ of students stated having sexual problems, so to control and deal with possible problems, couples need more counseling in various aspects of life are more ( Scott, MS., Paul, RA., Christine AJ., Howard, JM,2006:117)and(Halford, Simons ,2005:147 ). In this study, half of the students 64.3\% have stated counseling before marriage (Table 5). In the history of this issue, it is stated that regular marriage programs are common in the West, and necessary training is given in high schools and universities. Marriage compiled programs include solving problems, making decisions, making a living, meeting the expectations, beliefs and values are taught to $t$ young people in form of life skills, while in Iran no written programs have been developed or published in serious about marriage and engagement ( Stahmann,2000:104 ).

\section{Conclusions:-}

The results of the analysis of research data show that in general, students look positively toward marriage, but act with caution. From this perspective, marriage can lead to happiness in life. Female students assume give and take in dealing with life's problems and often believed in getting pre-marital counseling and see life training programs in the form of life skills inevitable from the experts, sociologists, and psychologists.

The results of this study are obtained in the academic year 2014-15 from students of Payam Noor University of Urmia and do not include other groups (not generalizable). In this regard, a study on a larger scale with a more population can be conducted and the views of young people towards getting married and meeting the requirements of the engagement period can be interviewed and reviewed.

\section{References:-}

1. Altun, E. (1994). "Healthy Families Healthy Communities Family". C.U. School Nursing InternationalNurses' Day, Sivas, Rector Publisher , p.15-22.

2. Arslan, H., Engin, F., Can, O. (2000). "Two of Premarital Reproductive Health towards Education and Determination of Counseling Requirements", 1. International \& VIII. National Nursing Congress, Antalya, p.94-98.

3. Barbara, De Angelis. (1993). "Are You the One for Me"? Dell; Reprint edition

4. Cigdem, A., Dikecligil, B. (1990). "Family and Family Types Over a Review; Family Articles Basic Concepts Publisher and Historical" Process premiership Family Research Institution Press,p.206-207.

5. Dunn, KM., Croft, PR., Hackett, GI. (2000). "Satisfaction in the sex life of a general population sample", Journal of Sex and Marital Therapy, 26:141- 151.

6. Ekshi, B. (2005). "Marriage in the preparatory phase marriage of husband and wife candidates and thoughts on being parents". Family and Society Magazine, 2(8): 75-84.

7. Gunay, O. (1995) . "Family and Health , Family Health ,Manual", Ed:Yusuf Ozturk, Process, Kayseri, p.1-5.

8. Halford, WK., Simons, M. (2005)."Couple relationship education in Australia”. Family Process. 44 (2): 147159.

9. Kalkan, M., Kaya, SN. (2007). "Premarital relations evaluation The development of scale: validity and reliability study". Family and Society Magazine, 3(11):35-40. Family Therapy, The Association For Family Therapy 2000, Published by Blackwell Publishers, Oxford, 22:104-116. 2000. 
10. Lister Joseph, Ann Lamont ( 1992). " father of modern surgery". Creation 14 (2): 48-51. Lister married Syme's daughter Agnes and became a member of the Episcopal church

11. Martin, PD., Specter, G., Martin, M., Martin, D. (2003). " Expressed attitudes of adolescents toward marriage and family life. Adolescence", 38 (150): 359-367.

12. Mohammad Sadeghi ,M ,M .(2005). "Marriage and premarital education /-Bureau to prevent social harm, Cultural Deputy of the State Welfare Organization" -Tehran p.150

13. Ozguven, İE. (2000).” Marriage and Family Therapy”, PDREM Process ,Ankara, p.21

14. Ozvarıs, SB. (2001). "Premarital counseling, Maternal- Fetal Tip ve Perinatoloji”, Ankara, Medikal Network, pp.124-127.

15. Purnine, DM., Carey, MP. (1997). “ Interpersonel communication and sexual adjustment the roles of understanding and agreement", Journal of Consulting and Clinical Psychology, 65(6): 1017-1025.

16. Scott, MS., Paul, RA., Christine AJ., Howard, JM(2006). "Premarital education, marital quality, and marital stability: findings from a large, random household survey". Journal of Family Psychology. 20 (1): 117.

17. Silliman, B., Walter, RS. (2004). "Adolescents' perceptions of marriage and premarital couples education". Family Relations . 53 (5): 513-520.

18. Stahmann, RF. ( 2000). "Premarital counselling: a focus for family therapy”. Journal of Family Therapy, 22:104- 116.

19. Statistical Center of Iran .(2009). “Analysis of the characteristics of marriage in Iran”, Tehran

20. Stephen, F., Duncan, TB., Holman, CY. (2007). " Factors associated with involvement in marriage preparation programs”. Family Relations. 56 (3): 270-278.

21. Sullivan T. K., et all. ( 2004). “Predicting participation in premarital prevention programs: the health belief model and social norms", Family Process; 43(2): 175-193.

22. Suzer, F., Yildiz, A. (2005). "to be married concern status of the couple and counseling requirement", Zonguldak School of Health Sciences Health Education Research Journal, 1(2): 24-33.

23. TC Prime Ministry Family Research Council -TÜİK. (2006). “ Family Structure Survey”. http://aile.gov.tr/aileist. Date of access 18.02.2008. Family Research Council Publication. Ankara.

24. Turkarslan, Nesrin, Demirkan, Semra Yurtkuran. (2007). " "University final year students views and opinions regarding the marriage institution".Ankara. Family and Social Research General Directorate, 175 s. (ASAGEM ; Press No. 132).

25. Vural, BK., Temel, AB. (2007) "Premarital Individuals Participation in the Mentoring Program Investigation of Forecasting”. 11. National Public Health Congress, 23-26 October. Denizli. p. 34. 